\title{
Meninjau Aspek Pencegahan Fraud: Studi Kasus di KPP Pratama Sukabumi
}

Jurnal Akuntansi Terapan Indonesia Vol 3 No 2 Hal 94-104 October 2020

\section{Affiliation:}

Universitas Muhammadiyah

Yogyakarta, Indonesia

\section{*Correspondence:}

ani.andreanjani@gmail.com

This Article is Avalilable in: https://journal.umy.ac.id/index. php/jati/article/view/9437

DOI:

https://doi.org/10.18196/jati.030230

\section{Citation:}

Gunawan, B., Hanjani, A., \& Humairoh, N. (2020). Meninjau Aspek

Pencegahan Fraud: Studi Kasus di KPP Pratama Sukabumi. Jati: Jurnal Akuntansi Terapan Indonesia, 3(2), 94104.

\section{Article History}

Received:

24 July 2020

Reviewed:

23 Agustus 2020

Revised:

18 September 2020

Accepted:

20 October 2020

Topic Article:

Auditing

\author{
Barbara Gunawan ${ }^{1}$, Andreani Hanjani*2, Nur Aisyah Humairoh ${ }^{3}$
}

\begin{abstract}
:
The purpose of this study was to determine fraud prevention factors in KPP Pratama Sukabumi Regency. The investigated factors are individual morality, rule obedience, compensation, and the whistleblowing system. The population in this study are KPP Pratama employees of Sukabumi Regency, West Java, with a sample of 30 employees who were selected by purposive sampling and received delegations for the inspection, billing, extensification, and supervision sections. The research used a quantitative research model with questionnaires for data collection. The results showed that individual morality and rule obedience influence fraud prevention. In comparison, compensation and whistleblowing systems do not affect fraud prevention. Consequently, this research's implication is vital for the Tax Office to determine the probable factors of fraud prevention so that there are no further acts of fraud committed by Tax Office employees (who are prone to fraud).
\end{abstract}

Keywords: Individual Morality, Compensation, Compliance to Rules, Whistleblowing System, and Fraud Prevention.

\section{Abstrak:}

Tujuan dari penelitian ini adalah untuk mengetahui faktor pencegahan fraud di KPP Pratama Kabupaten Sukabumi. Adapun faktor yang diteliti adalah moralitas individu, ketaatan aturan, kompensasi, dan whistleblowing system. Populasi dalam penelitian ini adalah karyawan KPP Pratama Kabupaten Sukabumi Jawa Barat, dengan sampel sebanyak 30 karyawan yang dipilih dengan purposive sampling dan yang menerima delegasi seksi pemeriksaan, seksi penagihan, seksi ekstensifikasi, dan seksi pengawasan. Metode penelitian yang digunakan adalah penelitian kuantitatif dengan pengumpulan data menggunakan kuesioner. Hasil penelitian menunjukkan bahwa moralitas individu dan ketaatan aturan berpengaruh terhadap pencegahan fraud. Sedangkan kompensasi dan whistleblowing system tidak berpengaruh terhadap pencegahan fraud. Implikasi penelitian ini penting bagi Kantor Pelayanan Pajak untuk mengetahui faktor-faktor yang mempengaruhi pencegahan fraud agar tidak terjadi tindakan kecurangan yang dilakukan oleh pegawai Kantor Pelayanan Pajak yang rentan terjadinya tindakan fraud.

Kata Kunci: Moralitas Individu, Kompensasi, Ketaatan Aturan, Whsitleblowing System, dan Pencegahan Fraud. 


\section{PENDAHULUAN}

Fraud atau kecurangan yang banyak terjadi dapat dilakukan oleh siapa saja, baik yang bekerja pada perusahaan swasta, BUMN, atau bahkan pegawai pemerintah negara. Kecurangan dapat meliputi tindak korupsi, penyalahgunaan asset, dan mani-pulasi laporan keuangan. Laporan ACFE tahun 2017 menunjukkan masih banyak korupsi yang dilakukan oleh pegawai pemerintah salah satunya dilakukan oleh pegawai kantor pajak. Salah satu kasus fraud yang terjadi di kantor pajak adalah pada Desember 2017, tersangka inisial AP, seorang PNS KPP Madya Gambir dan JJ mantan PNS KPP Madya Jaksel, ditangkap terkait kasus korupsi yang dilakukan. Keduanya bekerja sama dan menerima suap penjualan faktur pajak sebesar suap yang diterima sebesar Rp. 14.000.000.000 (empat belas miliar Rupiah) dan keduanya diancam hukuman pidana penjara diatas 5 tahun. Dalam kasus ini penyidik sebelumnya telah menetapkan JJ sebagai tersangka, yang pada saat itu bekerja dibawah AP. JJ diduga melakukan penyalahgunaan wewenang dengan menerima suap dari beberapa perusahaan baik secara langsung atau lewat perantara (Medistiara, 2017, http://news.detik.com/berita/d 3639898/kejagung-tahan-pegawai-pajak-yang-terima-suaprp-14-miliar, 20 Desember 2018). Kasus fraud lainnya yang terjadi di KPP yaitu Kasus RA merupakan petugas pajak dengan jabatan account representative (AR) Kantor Pelayanan Pajak (KPP) Pratama Bangka. RA tertangkap saat Polda Bangka menangkapnya saat sedang bertransaksi atas laporan korban. Kepolisian Daerah Bangka menangkap seorang pegawai pajak yang ketahuan memeras masyarakat sebesar $\mathrm{Rp} 50$ juta (https://www.liputan6.com/bisnis/read/3472501/ dirjen-pajak-soal-anak-buahnya-kena-ottbukan-karena-gaji-kecil). Selain itu kasus lain yang melibatkan Pegawai Kantor Pajak Ambon, Sulimin Ratmin, divonis 7 tahun penjara dan denda Rp 250 juta subsider 6 bulan kurungan. Dia dinyatakan terbukti menerima suap dari wajib pajak bernama Anthony Liando (sumber https://news.detik.com/berita/d-4495191/pegawai-kantor-pajak-ambon-divonis-7tahun-bui-di-kasus-suap).

Dalam praktiknya fraud identik dengan cara individu beretika, ketika mereka memiliki etika yang baik mereka cenderung akan menjauhi fraud, sebaliknya ketika memiliki etika yang rendah keinginan untuk bertindak menyimpang akan semakin tinggi. Etika disini dapat diartikan sebagai tingkat moralitas individu. Menurut beberapa peneliti, bahwa tingkat moralitas yang dimiliki setiap individu akan memengaruhi keinginan mereka untuk bertindak curang (Tarigan dkk., 2016). Ketika seseorang memiliki moral yang baik dapat diharapkan dia akan bertindak sesuai dengan keinginan perusahaan, dan akan menghindari perilaku yang menyimpang (Aprila dkk., 2017). Berdasarkan hasil Survei ACFE Indonesia, ditemukan bahwa pelaku fraud kebanyakan berasal dari pegawai-pegawai yang extravaganza lifestyle atau tuntutan lifestyle-nya tinggi, dan akan sangat terdorong apabila kompensasi atau reward yang mereka dapatkan tidak sesuai dengan apa yang mereka inginkan. Pemberian kompensasi yang sesuai akan memperkecil kecenderungan seseorang untuk bertindak curang, karena individu akan merasa puas dengan apa yang telah mereka dapatkan (Frilia dkk., 2015).

Faktor lain seseorang melakukan fraud adalah karena adanya peluang. Seseorang akan terdorong melakukan tindakan menyimpang ketika mereka melihat besarnya peluang untuk melakukan tindakan tersebut, misalnya karena lemahnya sistem pengendalian internal. Sehingga sangat penting bagi tiap instansi untuk memaksimalkan SPI, karena SPI dapat dilakukan dengan menerapkan sistem pengawasan dan pengaduan yang baik, inilah yang dimaksud dengan whistleblowing system (Wardanah dkk., 2017). Penerapan whistleblowing system sebagai sistem pengaduan dan pengawasan berbagai tindakan yang menyimpang dalam organisasi tidak hanya dapat dilakukan oleh atasan, namun semua lapisan dalam instansi seperti pegawai biasa (Wijaya dkk., 2017). 
Studi terkait pencegahan fraud pada Kantor Pelayanan Pajak masih jarang dilakukan sampai saat ini. Penelitian yang ditemukan kebanyakan melakukan studi pada perusahaan swasta dan kantor dinas yang bukan Kantor Pelayanan Pajak seperti Peneliti Mufidah dan Sari (2018), Shintadevi (2015), dan Nugroho (2015). Hasil penelitian Mufidah dan Sari (2018) pada Travel Haji dan Umrah di Kotamadya Jambi menunjukkan pengaruh antara ketaatan aturan dan pencegahan fraud. Untuk pengaruh pemberian kompensasi terhadap upaya mencegah fraud, belum banyak yang melakukan, sehingga penelitian ini berpatokan pada penelitian Shintadevi (2015) namun dengan variabel dependen kecenderungan kecurangan, dianggap sama, menurunnya kecenderungan kecurangan menunjukkan berhasilnya suatu organisasi meningkatkan upaya untuk mencegah fraud. Sementara itu Nugroho (2015) menemukan bahwa Persepsi Karyawan Mengenai Whistleblowing System berpengaruh signifikan positif terhadap Pencegahan Fraud. Berangkat dari masih sedikitnya referensi riset yang membahas mengenai pencegahan fraud di Kantor Pajak, sementara isu ini merupakan topik hangat untuk diteliti, maka penelitian ini bertujuan untuk mengetahui pengaruh moralitas individu, kompensasi, ketaatan aturan, dan whistleblowing system terhadap pencegahan fraud di KPP Pratama Kabupaten Sukabumi.

Kecurangan atau fraud yang dikemukakan oleh Standar Profesi Akuntansi Publik dalam Nugroho (2015) merupakan suatu tindakan yang menyebabkan timbulnya salah saji dalam pelaporan. Seseorang melakukan tindakan fraud bukan tanpa alasan, sehingga untuk mencegah terjadinya kecurangan perlu dilakukan pengeliminasian faktor-faktor yang mendorong terjadinya fraud (Dewi dkk., 2017).

Fraud mencakup berbagai tipu daya yang dilakukan manusia yang digunakan untuk mengambil keuntungan dari pihak lain secara pribadi, pelaku penipuan dianggap tidak jujur dan licik (Mangala dan Kumari, 2015). Kecurangan dilakukan oleh seseorang dengan berbagai macam cara yang tentu saja tindakan itu dilakukan untuk mendapatkan manfaat dari orang lain meskipun dengan cara yang salah, menyembunyikan fakta sebenarnya, pelaku senantiasa memiliki rencana licik dan berbagai cara yang tidak wajar untuk menipu orang lain dan menyebabkan penderitaan (Mangala dan Kumari, 2015). Dengan demikian diperlukan suatu upaya untuk mencegah terjadinya fraud, pencegahan fraud dilakukan agar tidak terjadi tindakan-tindakan yang menyimpang yang dapat dilakukan oleh pegawai instansi atau karyawan perusahaan, yang tentu saja dapat merugikan berbagai pihak (Nugroho, 2015).

Salah satu upaya suatu instansi untuk menghindari kerugian dari tindak kecurangan adalah dengan mengetahui bagaimana moral pegawai atau karyawan, sehingga dapat memberi arahan agar pegawai dapat memiliki nilai moral yang baik, sehingga dapat memperlemah kecenderungan untuk bertindak curang pada perusahaan (Aprila dkk., 2017). Moralitas sangat berkaitan dengan baik dan buruknya tingkah laku seseorang, yang didasari pada norma yang berlaku pada masyarakat. Namun setiap tindakan yang manusia lakukan, persepsi baik buruknya tindakan itu akan berbeda antara individu yang satu dan individu yang lain. Kemudian, dapat diartikan bahwa moral adalah kemampuan penalaran setiap individu dalam menghadapi masalah, berbagai situasi yang mereka hadapi akan mendorong mereka untuk menilai terlebih dahulu tentang tindakan yang etis atau tidak etis (Nugroho, 2017). Penelitian yang dilakukan Wardana dkk., (2017) menunjukkan hasil bahwa moralitas aparat berpengaruh positif terhadap pencegahan fraud.

Selain moralitas, pemberian kompensasi yang tepat dapat mengurangi keinginan para pegawai untuk korupsi di lembaga pemerintahan, karena terpenuhinya kebutuhan fisik pegawai dengan menaikkan gaji mereka (Purnamasari dan Amalia, 2015). Diperlukan suatu struktur kompensasi yang baik untuk dapat dijadikan sebagai alternatif manajemen dalam menurunkan tingkat kecurangan akuntansi, serta meningkatnya kesadaran untuk mencapai kinerja yang lebih baik (Thoyibatun, 2012). Dengan demikian pemberian kompensasi yang sesuai pada setiap pegawai diharapkan akan mengurangi tingkat kecenderungan mereka 
untuk bertindak menyimpang. Purnamasari dan Amalia (2015) pemberian kompensasi yang cukup atau menaikkan gaji pegawai dapat mencegah fraud, karena kebutuhan fisik mereka akan tercukupi sehingga mereka tidak akan memiliki niat untuk melakukan korupsi, penyelewengan dana dan lain sebagainya.

Aprila dkk. (2017) dan Wijaya dkk. (2017) menunjukkan bahwa pemberian kompensasi berpengaruh negatif terhadap kecenderungan kecurangan, ini berarti pemberian kompensasi efektif untuk mengurangi dan mencegah fraud pada organisasi. Sedangkan Cendekia dkk. (2016) menyatakan bahwa tidak terdapat pengaruh yang signifikan antara kompensasi dan pencegahan fraud, ini juga didukung oleh Fauzya (2017) menemukan bahwa ada pengaruh kesesuaian kompensasi terhadap pencegahan fraud.

Ketaatan dapat diartikan sebagai sikap patuh terhadap aturan dan Pemerintah, sedangkan aturan sendiri merupakan cara yang telah ditetapkan dan diharuskan untuk dijalani. Pada setiap instansi, terdapat pedoman dan aturan yang digunakan dalam memajemen instansi, dalam penentuan tujuan atau prosedur kegiatan yang dilakukan dalam organisasi (Ade, 2017). Dalam pelaksanaan di kantor pemerintahan seperti Dirjen Pajak dan instansi lainnya, tentu telah ditetapkan aturan yang mendasari kegiatan yang mereka lakukan. Shintadevi (2015), aturan akuntansi yang telah dibuat sedemikian rupa haruslah menjadi dasar dalam operasional suatu instansi atau entitas. Pada kantor pelayanan pajak sendiri, mereka tidak memiliki aturan tersendiri atau aturan khusus di tiaptiap kantor, semua aturan yang digunakan berhubungan dengan operasional dan kinerja pegawai ditetapkan oleh Ditjen Pajak dan Kementrian Keuangan. Bhasin' (2016) menemukan bahwa kecurangan yang terjadi pada Satyam disebabkan karena masih lemahnya aturan terhadap CG, disisi lain sangat penting untuk menjunjung tinggi hukum dan aturan dalam organisasi.

Perbuatan dan tingkah laku seorang individu juga tergantung dari tingkat ketaatannya terhadap aturan (Junia, 2016). Ketika seorang individu taat terhadap aturan yang berlaku dalam organisasinya, dia akan bertindak sesuai dengan prosedur yang ada, dia tidak akan melakukan penyimpangan, serta ada rasa takut akan hukuman dan sanksi apabila melanggar aturan tersebut. Mufidah dan Sari (2018) menyatakan bahwa membangun persepsi untuk taat terhadap aturan dan takut terhadap sanksi yang ada akan mencegah terjadinya fraud.

KNKG (2008) mendefinisikan Whistleblowing sebagai suatu tindakan pengaduan atas perbuatan yang melanggar hukum, tindakan tidak etis, atau tindakan ilegal yang akan merugikan instansi dan pihak lain yang berkepentingan, tindakan pengungkapan yang dapat dilakukan oleh semua pihak, baik karyawan, pimpinan organisasi, maupun lembaga lain. Whistleblowing dapat dilakukan dengan dua cara yaitu dari dalam (internal) dan dari luar (eksternal). Whistleblowing yang dilakukan secara internal dapat berupa pengaduan terhadap tindakan kecurangan kepada pimpinan organisasi atau pihak lain yang berwenang dalam whistleblowing system. Sedangkan dari eksternal terjadi jika seorang karyawan mengetahui ada karyawan lain yang melakukan kecurangan, kemudian melaporkan kecurangan tersebut pada masyarakat karena tindakan tersebut dapat merugikan masyarakat (Wardanah dkk., 2017).

Whistleblowing system merupakan sistem yang dibentuk berdasarkan kriteria kecurangan yang dilaporakan, dilakukan tindak lanjut terhadap laporan yang diterima, adanya pemberian perlinduangan serta penghargaan atas laporan yang dilakukan, selain itu ada hukuman yang diberikan untuk pihak terlapor (Nugroho, 2015). Whistleblowing system dibentuk oleh Sarbanex-Oxley Act of Company Audit Commite mengharuskan Komite Audit suatu organisasi untuk menerima setiap laporan, kemudian memproses laporan, dan melakukan tindak lanjut terhadap laporan pengaduan yang tentu saja berkaitan dengan masalah akuntansi, pengendalian internal, atau bahkan auditing, dengan tetap menjaga kerahasiaan identitas pelapor. 
Salah satu manfaat diselenggarakannya whistleblowing system adalah untuk menimbulkan seseorang merasa enggan untuk melakukan kesalahan karena merasa diawasi oleh sistem pelaporan yang efektif (Wijaya dkk., 2017). Wardanah dkk. (2017) menemukan bahwa whistleblowing system berpengaruh signifikan positif terhadap pencegahan fraud, yang artinya jika suatu organisasi dapat menerapkan sistem pengaduan dengan efektif maka dapat mencegah terjadinya kecurangan dalam organisasi. Begitupun dengan Nugroho (2015) yang menjelaskan pengaruh secara positif antara whistleblowing system dan pencegahan fraud yang artinya semakin efektif penerapan sistem ini dalam organisasi, semakin pegawai akan menghindari kecurangan karena merasa takut diadukan dan akan merasa diawasi.

\section{METODE PENELITIAN}

Objek dalam penelitian adalah Kantor Pelayanan Pajak Pratama Sukabumi. Peneliti memilih KPP Pratama Sukabumi karena tidak ada pegawai yang melakukan tindakan fraud selama ini. Data pada penelitian ini adalah data primer, yaitu kuesioner yang diperoleh dari para informan penelitian yang merupakan pegawai Kantor Pajak Pratama Sukabumi terdiri dari 4 seksi yaitu Seksi Penagihan, Seksi Pemeriksaan, Seksi Ekstensifikasi, dan Seksi Pengawasan. Metode penetapan sampel yang digunakan adalah purposive sampling, yang dilakukan dengan mempertimbangkan kriteria tertentu untuk memilih populasi yang ada sebagai sample. Variabel Dependen dalam penelitian ini adalah Pencegahan Fraud dan variable independennya adalah Moralitas Individu, Kompensasi, Ketaatan Aturan Akuntansi, Whistleblowing System. Metode yang digunakan dalam penelitian ini adalah Analisis Regresi Berganda. Adapun model yang digunakan:

$\begin{array}{ll}\mathrm{Y}=\boldsymbol{\alpha}-\boldsymbol{\beta}_{1} \mathrm{X}_{\mathbf{1}}-\boldsymbol{\beta}_{\mathbf{2}} \mathrm{X}_{\mathbf{2}}-\boldsymbol{\beta}_{\mathbf{3}} \mathrm{X}_{\mathbf{3}}-\boldsymbol{\beta}_{\mathbf{4}} \mathrm{X}_{\mathbf{4}}+\mathbf{e} \\ \text { Keterangan : } & \\ \mathrm{Y} & \text { : Pencegahan Fraud } \\ \mathrm{X}_{1} & \text { : Moralitas Individu } \\ \mathrm{X}_{2} & \text { : Kompensasi } \\ \mathrm{X}_{3} & \text { : Ketaatan Aturan Akuntansi } \\ \mathrm{X}_{4} & : \text { Whistleblowing System } \\ \alpha & : \text { Konstanta } \\ \beta_{1}-\beta_{4} & \text { : Koefisien Regresi } \\ \mathrm{e} & \text { : error }\end{array}$

Kriteria untuk melihat apakah faktor Moralitas Individu, Kompensasi, Ketaatan Aturan Akuntansi, dan Whistleblowing System berpengaruh terhadap Pencegahan Fraud dapat dilihat dari nilai signifikansi. Jika nilai signifikansi lebih kecil dari alpha (0.05) maka dapat dikatakan bahwa Moralitas Individu, Kompensasi, Ketaatan Aturan Akuntansi, dan Whistleblowing System berpengaruh terhadap Pencegahan Fraud; dan sebaliknya.

\section{Definisi Operasional Variabel Penelitian Variabel Dependen Pencegahan Fraud}

Pencegahan fraud merupakan suatu tindakan untuk menolak dan menahan segala bentuk tindakan yang menyimpang, tidak jujur, dan akan menyebabkan kerugian bagi organisasi atau pihak lainnya. Kuesioner yang digunakan untuk variabel Pencegahan Fraud diadopsi dari penelitian Nugroho (2015) dengan indikatornya adalah fraud tree, yang terdiri dari 3 ranting utama, yaitu korupsi, penyalahgunaan aset, dan kecurangan laporan keuangan. Diukur dengan menggunakan skala likert 5-1 Sangat Tidak Setuju (STS), Tidak Setuju (TS), Netral (N), Setuju (S), Sangat Setuju (SS). 


\section{Variabel Independen Moralitas Individu}

Menurut Amalia (2015) moralitas adalah pelaksanaan kewajiban karena hormat terhadap hukum, sedangkan hukum itu sendiri tertulis dalam hati manusia. Dengan kata lain moralitas adalah tekad untuk mengikuti apa yang ada dalam hati manusia dan disadari sebagai kewajiban mutlak. Moralitas disini diukur dengan mengadopsi kuesioner dari Penelitian Amalia (2015). Pertanyaan berupa kasus dilematis dengan indikator yaitu: Moral Murni dan Moral Terapan. Diukur dengan menggunakan skala likert 1-5 Sangat Tidak Setuju (STS), Tidak Setuju (TS), Netral (N), Setuju (S), dan Sangat Setuju (SS).

\section{Kompensasi}

Indikator yang digunakan dalam pebelitian ini adalah (1) kompensasi langsung dan (2) kompensasi tidak langsung. Kuesioner yang digunakan diadopsi dari penelitian Amalia (2015), yang terdiri dari empat pertanyaan, dan pengukuran menggunakan skala likert yang terdiri Sangat Tidak Setuju (STS), Tidak Setuju (TS), Netral (N), Setuju (S) dan Sangat Setuju (SS).

\section{Ketaatan Aturan}

Kuesioner untuk variabel ini terdiri dari tujuh pertanyaan yang diadopsi dari penelitia Wilopo (2006), dengan instrumen kuesioner yang dikembangkan dari IAI (1998) tentang Kode Etik Akuntan, dengan indikator diantaranya (1) kepentingan publik, (2) integritas, (3) objektifitas, (4) kerahasiaan, (5) kehati-hatian, (6) konsistensi, dan (7) standar teknis. Pengukuran pertanyaan kuesioner menggunakan skala likert yang terdiri dari Sangat Tidak Setuju (STS), Tidak Setuju (TS), Netral (N), Setuju (S), dan Sangat Setuju (SS).

\section{Whistleblowing System}

Pada variabel whistleblowing system, terdapat tiga hal yang menjadi indikator penelitian, yaitu (1) aspek struktur Whistleblowing system, (2) aspek operasional Whistleblowing system, dan (3) aspek perawatan Whistleblowing system. Dimana pengukuran kuesioner diadopsi dari penelitian Nugroho (2015). Pada kuesioner menggunakan pengukuran dengan skala likert yang terdiri dari Sangat Tidak Setuju (STS), Tidak Setuju (TS), Netral (N), Setuju (S), Sangat Setuju (SS).

\section{HASIL DAN PEMBAHASAN}

\section{Karakteristik Responden}

Karakteristik responden yang menjadi populasi dalam penelitian ini dibagi menjadi beberapa kelompok berdasarkan jenis kelamin, umur, dan jenjang pendidikan. Tabel 1 , Tabel 2, Tabel 3, dan Tabel 4 menyajikan karakteristik responden menurut jenis kelamin, rentang usia, lama bekerja, dan jenjang pendidikan.

Tabel 1 Karakteristik Responden Berdasarkan Jenis Kelamin

\begin{tabular}{ccc}
\hline Jenis Kelamin & Jumlah & Persentase \\
\hline Perempuan & 3 & $10 \%$ \\
Laki-laki & 27 & $90 \%$ \\
Total & 30 & $100 \%$
\end{tabular}

Tabel 1 menunjukkan bahwa responden yang berjenis kelamin pria dalam penelitian ini berjumlah 27 orang dan yang berjenis kelamin perempuan berjumlah 3 orang. Artinya responden dalam penelitian ini dodominasioleh kaum pria. 
Tabel 2 Karakteristik Responden berdasarkan Rentang Usia

\begin{tabular}{ccc}
\hline Rentan Usia & Jumlah & Persentase \\
\hline $20-25$ & 7 & $23,3 \%$ \\
$26-31$ & 2 & $6,7 \%$ \\
$32-37$ & 8 & $26,7 \%$ \\
$38-43$ & 9 & $30 \%$ \\
$44-49$ & 3 & $10 \%$ \\
$50-55$ & 1 & $3,3 \%$ \\
Total & 30 & $100 \%$ \\
\hline
\end{tabular}

Tabel 2 diketahui bahwa responden dalam penelitian ini sebanyak 9 orang berusia 3843 tahun, dilanjutkan dengan usia 32-37 tahun sebanyak 8 orang, diurutan ketiga dengan rentang usia 20-25 tahun sebanyak 7 orang, responden yang berumur 44-49 tahun sebanyak 3 orang, berumur 26-31 tahun sebanyak 2 orang dan rentan usia 50-55 tahun hanya 1 orang. Dengan demikian dapat disimpulkan bahwa mayoritas responden berusia antara $32-43$ tahun, yang merupakan usia paling produktif, artinya sudah mempunyai pengalaman bekerja, namun masih cukup jauh dari usia pension.

Tabel 3 Karakteristik Responden berdasarkan Lama Bekerja

\begin{tabular}{ccc}
\hline Rentan Lama Bekerja & Jumlah & Persentase \\
\hline 1-5 Tahun & 3 & $10 \%$ \\
6-10 Tahun & 7 & $23,3 \%$ \\
>10 Tahun & 20 & $66,7 \%$ \\
\hline & 30 & $100 \%$ \\
\hline
\end{tabular}

Tabel 3 menunjukkan responden lama bekerja 1-5 tahun berjumlah 3 orang. Lama bekerja 6-10 tahun berjumlah 7 orang. Ada 20 pegawai atau sebanyak $66,7 \%$ dari responden yang ada telah bekerja dibidang perpajakan selama lebih dari 10 tahun sehingga mereka tentu mempunyai pengalaman yang cukup dalam dunia perpajakan.

Tabel 4 Karakteristik Responden berdasarkan Jenjang Pendidikan

\begin{tabular}{ccc}
\hline Jenjang Pendidikan & Jumlah & Persentase \\
\hline D3 & 12 & $40,0 \%$ \\
S1 & 6 & $20,0 \%$ \\
S2 & 2 & $6,7 \%$ \\
S3 & 0 & $0 \%$ \\
\hline Total & 30 & $100 \%$ \\
\hline
\end{tabular}

Tabel 4 menunjukkan responden dalam penelitian ini sebanyak 12 orang berjenjang pendidikan D3, kemudian sebanyak 6 orang dengan jenjang pendidikan S1, dan hanya 2 orang pegawai yang menempuh pendidikan hingga S2 dalam penelitian ini.

\section{Hasil Uji Regresi}

Teknik analisis yang digunakan adalah regresi berganda dengan dengan meregresi Moralitas Individu, Kompensasi, Ketaatan Aturan, dan Whistleblowing System terhadap Pencegahan Fraud.

\section{Uji Koefisien Determinasi}

Tabel 5 menunjukkan nilai Adjusted $R^{2}$ sebesar 0,838 (83,8\%). Nilai ini menunjukkan bahwa variabel moralitas individu, kompensasi, ketaatan aturan dan whistleblowing system dapat menjelaskan informasi yang digunakan untuk memprediksi variasi perubahan pencegahan fraud.

Tabel 5 Hasil Uji Analisis Regresi Berganda

\begin{tabular}{crr}
\hline R & R Square & Adjusted R Square \\
\hline 0,928 & 0,860 & 0,838
\end{tabular}

Sumber: Hasil Output SPSS 


\section{Uji Statistik F}

Tabel 6 dapat dilihat bahwa dalam pengujian regresi berganda menunjukkan tingkat signifikansi $0,000<0,05$. Hasil tersebut dapat menunjukkan bahwa variabel moralitas individu, kompensasi, ketaatan aturan dan whistleblowing system secara bersama-sama memengaruhi pencegahan fraud.

\begin{tabular}{lcc}
\multicolumn{3}{c}{ Tabel 6 Hasil Uji Analisis Regresi Berganda } \\
\hline F & Sig \\
\hline Regression & 38,510 & 0,0000 \\
Sumber: Hasil Output SPSS &
\end{tabular}

\section{Uji Statistik t}

Tabel 7 menunjukkan bahwa moralitas individu berpengaruh positif terhadap pencegahan fraud. Hal tersebut tampak dari nilai signifikansi yang lebih kecil dari alpha $(0,041<0,05)$. Artinya semakin tinggi moralitas individu yang dimiliki pegawai, semakin dapat mencegah terjadinya fraud.

Tabel 7 Hasil Uji Analisis Regresi Berganda

\begin{tabular}{lccc}
\multicolumn{4}{c}{ Tabel 7 Hasil Uji Analisis Regresi Berganda } \\
\hline Constant & $\mathrm{B}$ & $\mathrm{T}$ & Sig \\
Moralitas Individu & 11,905 & 8,071 & 0,000 \\
Kompensasi & 0,448 & 2,643 & 0,041 \\
Ketaatan Aturan & 0,092 & 0,723 & 0,476 \\
Whistleblowing System & 0,281 & 3,918 & 0,001 \\
Sumber: Hasil Output SPSS & 0,058 & 1,335 & 0,194 \\
\hline
\end{tabular}

Temuan penelitian ini sesuai dengan temuan Wardanah dkk. (2017) yang juga menunjukkan pengaruh positif antara moralitas dan pencegahan fraud, yang mana semakin tingginya tingkat moral yang dimiliki aparat, akan semakin meningkatkan upaya pencegahan fraud. Selain itu penelitian ini sesuai dengan Wijaya dkk. (2017) yang menemukan bahwa moralitas individu berpengaruh negatif dengan kecenderungan kecurangan akuntansi, tentu saja semakin tinggi nilai moral seorang individu makan semakin kecil kecenderungannya melakukan kecurangan akuntansi, sehingga dapat mencegah terjadinya fraud dimasa depan. Namun temuan penelitian ini tidak didukung oleh Dewi dkk. (2017) yang menemukan jika moralitas individu tidak memiliki pengaruh yang signifikan terhadap pencegahan fraud. Tingkat moralitas yang tinggi belum tentu dapat mencegah pegawai pada suatu instansi terhindar dari tindakan kecurangan karena masih ada beberapa faktor yang mendorong pegawai melakukan tindakan kecurangan.

Hasil uji regresi yang ditunjukkan pada Tabel 7 hasil bahwa nilai sig 0,476>0,05. Sehingga dapat diketahui kompensasi tidak berpengaruh terhadap pencegahan fraud. Hasil penelitian ini menunjukkan bahwa meskipun pemberian kompensasi yang tinggi, belum tentu dapat mencegah terjadinya kecurangan akuntansi. Hasil penelitian ini sesuai dengan Cendekia dkk. (2016) bahwa pemberian kompensasi tidak akan menutup kemungkinan kecurangan akuntansi tetap terjadi, masih kurang efektifnya upaya pencegahan fraud melalui pemberian kompensasi. Begitupun Fauzya (2017) menyatakan bahwa kesesuaian kompensasi tidak berpengaruh terhadap kecenderungan kecurangan akuntansi, ini menunjukkan bahwa meskipun instansi atau organisasi memberikan kompensasi yang sesuai dengan kinerja pegawainya, belum dapat menjamin berkurangnya kecenderungan dia melakukan kecurangan. Hal ini menunjukkan bahwa meskipun instansi atau organisasi memberikan kompensasi yang sesuai dengan kinerja pegawainya, belum dapat menjamin berkurangnya kecenderungan dia melakukan kecurangan.

Hasil uji regresi pada Tabel 7 ditemukan nilai sig 0,001<0,05. Hasil tersebut menunjukkan bahwa ketaatan aturan berpengaruh positif terhadap pencegahan fraud. Artinya semakin tinggi ketaatan pegawai terhadap aturan yang ada semakin efektif upaya pencegahan fraud yang diterapkan. Ketaatan aturan merupakan sikap patuh dan taat 
seseorang terhadap aturan akuntansi yang menjadi pedoman mereka dalam melaksanakan operasional dalam instansi atau organisasi mereka. Ini berarti semakin seorang pegawai taat terhadap aturan, maka semakin akan bertindak sesuai dengan aturan yang ditetapakan, dan akan menurunkan kemungkinan untuk bertindak curang. Tentu saja membentuk karakter yang taat terhadap aturan menjadi upaya pencegahan fraud. Temuan penelitian ini sesuai dengan Mufidah dan Sari (2018) menemukan bahwa ketaatan aturan bepengaruh secara signifikan terhadap pencegahan fraud.

Hasil uji regresi pada tabel 7 nilai sig 0,194 >0,05. Hasil ini menunjukkan bahwa whistleblowing system tidak berpengaruh terhadap pencegahan fraud. Whistleblowing system tidak berpengaruh terhadap pencegahan fraud. Hasil penelitian justru membuktikan bahwa penerapan whistleblowing system tidak menjamin suatu instansi dapat terhindar dari tindak kecurangan. Whistleblowing system merupakan sistem pengaduan dan pengawasan yang diterapkan untuk mencegah tindakan-tindakan yang menyimpang yang dapat merugikan organisasi atau instansi yang ada, sistem ini dapat dilakukan oleh pemimpin atau oleh karyawan. Penelitian ini sesuai dilakukan Schutz dan Harutyunyan (2015) menjelaskan beberapa hal yang menyebabkan whistleblowing system tidak dapat bekerja dengan baik, salah satunya karena masih masih kurangnya niat dalam diri pelapor untuk melakukan whistleblowing tanpa adanya niat tertentu seperti keinginan untuk balas dendam atau untuk mendapatkan reward yang akan menguntungkan dirinya sendiri. Selain itu masih kurang kuatnya aturan yang melindungi dan membahas tentang tindak lanjut pengaduan yang dibuat. Namun berbeda dengan Nugroho (2015) menunjukkan bahwa adanya pengaruh positif antara whistleblowing system terhadap pencegahan fraud. Apabila seorang karyawan dapat memahami ketiga aspek whistleblowing system karyawan, maka akan merasa enggan untuk melakukan tindakan kecurangan serta cenderung untuk melaporkan tindakan yang dianggap sebagai tindakan menyimpang.

\section{KESIMPULAN}

Penelitian ini bertujuan untuk mengetahui pengaruh moralitas individu, kompensasi, ketaatan aturan, dan whistleblowing system terhadap pencegahan fraud di KPP Pratama Kabupaten Sukabumi. Hasil studi ditemukan bahwa Moralitas individu berpengaruh terhadap pencegahan fraud, Kompensasi tidak berpengaruh terhadap pencegahan fraud, Ketaatan aturan berpengaruh terhadap pencegahan fraud, dan whistleblowing system tidak berpengaruh terhadap pencegahan fraud. Implikasi penelitian ini penting bagi Kantor Pelayanan Pajak untuk mengetahui faktor-faktor yang mempengaruhi pencegahan fraud agar tidak terjadi tindakan kecurangan yang dilakukan oleh pegawai Kantor Pelayanan Pajak yang rentan terjadinya tindakan fraud. Penelitian ini memiliki keterbatasan yaitu hanya satu obyek saja yang digunakan dalam studi kasus yang mana tidak dapat digeneralisir secara luas untuk seluruh Kantor Pelayanan Pajak di Indonesia. Oleh karena itu penelitian selanjutnya disarankan untuk membuat penelitian dengan desain berbeda dengan menambah obyek penelitian. Meskipun terdapat keterbatasan, hasil ini tetap memiliki kebermanfaatan sebagai informasi yang berguna bagi Kantor Pelayanan Pajak dalam menyikapi pencegahan terjadinya fraud.

\section{DAFTAR PUSTAKA}

Amalia, R.D. (2015). Pengaruh Keefektifan Pengendalian, Kesesuaian Kompensasi, Moralitas Aparat dan Asimetris Informasi terhadap Kecenderungan Kecurangan Akuntansi (Studi Empiris pada Pemerintah Daerah Kabupaten Siak Sri Indrapura). Jurnal Online Mahasiswa Fakultas Ekonomi UNRI. Vol. 2, No. 2. 


\section{Gunawan, Hanjani, Humairoh}

Pencegahan Fraud di KPP Pratama Sukabumi: Tinjauan Aspek Moralitas Individu, Ketaatan Aturan, Kompensasi, dan Whistleblowing System

Aprilia, N. P. (2017). Pengaruh Efektivitas Pengendalian Internal, Kesesuaian Kompensasi, Asimetri Informasi, dan Moralitas Manajemen terhadap Perilaku Tidak Etis dan Kecenderungan Kecurangan Akuntansi. Prosiding Simposium Nasional XX Jember. Vol. I, No. 29.

Bhasin', M. (2016). Creative Accounting Practices at Satyam Computers Limited: A Case Study of India's Enron. International Journal of Business and Social Research, Vol. 06, Issue. 06.

Cendekia, C., Syahza, A. (2016). Pengaruh Efektivitas Pengendalian Internal dan Kesesuaian Kompensasi terhadap Pencegahan Fraud pada PDAM Tirta Siak Pekan Baru. Jurnal Online Mahasiswa Bidang Keguruan dan Ilmu Pendidikan Universitas Riau. Vol. 3, No. 2.

Dewi, P. Y. (2017). Pengaruh Moralitas, Integritas, Komitmen Organisasi, dan Pengendalian Internal Kas terhadap Pencegahan Kecurangan (Fraud) dalam Pelaksanaan Program Subsidi Beras Bagi Masyarakat Berpendapat Rendah (Studi pada Desa di Kabupaten Buleleng). e-journal S1 Ak Universitas Pendidikan Ganesha. Vol. 8, No. 2.

Fauzya, I. (2017). Pengaruh Keefektifan Sistem Pengendalian Internal, Kesesuaian Kompensasi. Moralitas Individu, dan Asimetri Informasi terhadap Kecenderungan Kecurangan Akuntansi dengan Perilaku Tidak Etis sebagai Variabel Intervening pada BPPKAD Kabupaten Sragen. Skripsi, Universitas Islam Negeri Surakarta.

Mangala, D. K. (2015). Corporate Fraud Prevention and Detection: Revisiting The Literatur. Journal of Commerce and Accounting Research, Vol.4, No. 1.

Medistiara, Y. (n.d.). Retrieved 20 Desember, 2018, from Kejagung Tahan Pegawai Pajak yang Terima Suap Rp. 14 Miliar, https://news.detik.com/berita/d-3639898/kejagung-tahanpegawai-pajak-yang-terima-suap-rp-14-miliar, Diakses tanggal 20 Desember 2018 pk 11.00 WIB.

Mufiadah, d. S. (2018). Pengaruh Pengendalian Internal, Ketaatan Aturan Akuntans terhadap Akuntabilitas Keuangan dengan Pencegahan Kecurangan (Fraud) sebagai Variabel Intervening pada Travel Haji dan Umrah di Kotamadya Jambi. Journal of Economics and Business, Vol. 2, No. 2.

Nugroho V.O. (2015). Pengaruh Persepsi Karyawan Mengenai Whistleblowing System terhadap Pencegahan Fraud dengan Perilaku Etis sebagai Variabel Intervening pada PT Pagilaran, Skripsi Publikasi. Universitas Negeri Yogyakarta, Yogyakarta

Purnamasari, P. d. (2015). Fraud Preverention: Relevance to Religiosity and Spirituality in The Workplace . 2nd Global Conference on Business and Social Science. Vol. 211, 827-835.

Schultz, D. d. (2015). Combating Corruption: The Development of Whistleblowing Laws in The United States, Europe, and Armenia . International Comparative Jurisprudence, Vol. 01, 87 97.

Shintadevi, P.F. (2015). Pengaruh Efektivitas Pengendalian Internal, Ketaatan Aturan Akuntansi dan Kesesuaian Kompensasi Terhadap Etis Sebagai Variabel Intervening. Jurnal Nominal. Vol. VI, No. 2, 111-126.

Tarigan, L.B. (2016). Pengaruh Moralitas Individu, Asimetri Informasi, Efektivitas Pengendalian Internal, dan Ketaatan Aturan Akuntansi terhadap Kecenderungan Kecurangan Akuntansi (Studi pada BUMD Provinsi Riau). Jurnal Online Mahasiswa Fakultas Ekonomi Universitas Riau. Vol. 3, 1.

Thoyibatun, S. (2012). Faktor-Faktor yang Berpengaruh terhadap Perilaku Tidak Etis dan Kecenderungan Kecurangan Akuntansi serta Akibatnya terhadap Kinerja Organisasi . Jurnal Ekonomi dan Keuangan, Vol. 16, No. 2.

V.O., N. (2015). Pengaruh Persepsi Karyawan Mengenai Whistleblowing System terhadap Pencegahan Fraud dengan Perilaku Etis sebagai Variabel Intervening pada PT Pagilaran. Skripsi Publikasi, Universitas Negeri Yogyakarta, Yogyakarta.

Wardanah, A. S., (2017). Pengaruh Pengandalian Internal, Whistleblowing System, dan Moralitas Aparat terhadap Pencegahan Fraud pada Dinas Pekerjaan Umum Kabupaten Buleleng. ejournal S1 Ak Universitas Pendidikan Ganesha, Vol. 8, No. 2. 


\section{Gunawan, Hanjani, Humairoh}

Pencegahan Fraud di KPP Pratama Sukabumi: Tinjauan Aspek Moralitas Individu,

Ketaatan Aturan, Kompensasi, dan Whistleblowing System

Wijaya, D. S., (2017). Pengaruh Efektivitas Pengendalian Internal, Kesesuaian Kompensasi, Moralitas Individu, dan Whistleblowing terhadap Kecenderungan Kecurangan Akuntansi pada LPD di Kecamatan Gerokgak. e-journal S1 Ak Universitas Ganesha, Vol. 7, No. 1.

Wilopo. (2006). Analisis Faktor-Faktor yang Berpengaruh terhadap Kecenderungan Kecurangan Akuntansi: Studi pada Perusahaan Publik dan Badan Usaha Milik Negara di Indonesia. Prosiding Simposium Nasional Akuntansi IX Padang 